\title{
APLIKASI STRATEGI PRODUK, HARGA DAN PROMOSI PADA DEPOSITO BATARA IB DI PT BANK TABUNGAN NEGARA (PERSERO) KANTOR CABANG SYARIAH (KCS) MALANG
}

\author{
Fani Firmansyah \\ Anisa Luthfiana
}

Program Studi D-III Perbankan Syariah Fakultas Ekonomi UIN Maliki Malang Jln. Gajayana 50 Malang

Abstract

Third party funds in banking sector is a capital to carry out its business activities. Deposito Batara iB is one of the third party funds mudharabah mutlaqah. PT Bank Tabungan Negara (Persero) KCS Malang managed to get an increase in deposits to raise Batara iB in the last two years. In order to increase the fund, PT Bank Tabungan Negara (Persero) KCS Malang provide product strategy, pricing and promotions on Deposito Batara $i B$. This research was conducted using qualitative methods with the descriptive approach and the data collection techniques through interviews and documentation. Primary data obtained through interviews and documentation. Secondary data obtained from the object of research website. Data analysis using qualitative data analysis. Product strategy by creating a logo, motto and packaging in the form of features and services. Pricing strategy given PT Bank Tabungan Negara (Persero) KCS Malang by providing profit sharing ratio deposits, special provision (nisbah), does not apply administrative fees and penalty in their transactions. To introduce a Deposito Batara iB to customers, PT Bank Tabungan Negara (Persero) KCS Malang promote activities through various media. Use of advertising media, through personal selling, sales promotion and publicity.

Keywords: strategi produk, harga dan promosi 
Perbankan Syariah merupakan entitas bisnis yang berperan penting dalam kegiatan ekonomi. Terhadapnya perlahan tapi pasti telah mendapatkan landasan hukum positif. Paket Kebijakan Oktober 1988 (Pakto 88), Undang-undang (UU) Perbankan No. 7 Tahun 1992 tentang Perbankan sebagaimana telah diubah melalui UU No. 10 Tahun 1998, dan UU No. 21 Tahun 2008 tentang Perbankan Syariah menjadi dasar hukum bagi perkembangan dimaksud, serta memberikan sumbangan yang penting, inovatif, dan prospektif bagi operasional dan produk perbankan syariah dalam rangka memenuhi kebutuhan masyarakat (Khatibul Umam, 2009:1).

Sistem perbankan syariah telah menjadi sebuah dual-banking dalam kerangka Arsitektur Perbankan Indonesia (API) guna penyediaan jasa dengan barbasis syariah dan konvensional demi memenuhi kebutuhan masyarakat. Melalui sistem bagi hasil, Bank Syariah dapat memberikan alternatif sistem perbankan yanng adil bagi masyarakat dan pihak bank. Pertumbuhan yang semakin pesat ini ditandai dengan menjamurnya Bank Konvensional yang mulai membuka Cabang Syariah, baik yang akhirnya menjadi Bank Umum Syariah maupun dalam bentuk Unit Usaha Syariah. Salah satu diantara sekian banyak bank syariah adalah PT Bank Tabungan Negara (Persero) Syariah. PT Bank Tabungan Negara (Persero) Syariah merupakan Strategic Bussines Unit (SBU) dari PT Bank Tabungan Negara yang menjalankan prinsip syariah guna melayani tingginya minat masyarakat dalam pemanfaatan jasa keuangan syariah dan memperhatikan keunggulan prinsip perbankan syariah, adanya Fatwa MUI tentang bunga bank, serta melaksanakan hasil RUPS tahun 2004 (BTN, 2009). PT Bank Tabungan Negara (Persero) membuktikan kontribusinya dalam dunia perbankan syariah dengan membuka beberapa kantor cabang di beberapa kota. Salah satunya di kota Malang. PT Bank Tabungan Negara (Persero) KCS Malang ini berusaha untuk memenuhi keinginan nasabah di kota Malang dan sekitarnya. Meluncurkan produk-produk dan layanan jasa syariah yang menarik dapat memberikan sebuah fasilitas jasa keuangan kepada nasabah.

Pada dunia perbankan, dana pihak ketiga merupakan sebuah modal untuk melaksanakan aktivitas bisnisnya. Melalui dana pihak ketiga sebuah bank mampu memberikan pinjaman kepada nasabah yang dapat memberikan keuntungan bagi pihak bank. Dana pihak ketiga pada bank dalam bentuk simpanan. Begitu pula pada PT Bank Tabungan Negara (Persero) KCS Malang yang memiliki produk dana pihak ketiga dalam bentuk simpanan. PT Bank Tabungan Negara (Persero) KCS Malang melakukan usaha peningkatan dana pihak ketiga melalui produk pendanaan. Pendanaan tersebut berupa Tabungan Batara iB, Giro iB dan Deposito Batara iB. Pada PT Bank Tabungan Negara (Persero) KCS Malang, Deposito Batara iB memberikan kontribusi yang cukup tinggi untuk meningkatkan dana pihak ketiga. Deposito Batara iB adalah produk penyimpanan dana dalam bentuk deposito dengan akad mudharabah mutlaqah, di mana tidak adanya pembatasan penggunaan dana dari shahibul maal (pemilik dana). Deposito Batara iB bertujuan untuk investasi dalam jangka waktu tertentu sesuai pilihan dan kebutuhan nasabah. 
Kegiatan investasi yang semakin menarik minat nasabah, menjadi salah satu alasan deposito memiliki potensi yang besar. Deposito Batara iB memiliki jangka waktu sehingga nasabah tidak melakukan penarikan dananya setiap saat. Dibandingkan dengan Tabungan Batara iB atau Giro Batara iB, Deposito Batara iB memiliki ranah yang cukup aman untuk simpanan modal dana bagi pihak bank karena pada giro dan tabungan nasabah dapat melakukan penarikan setiap saat. Sehingga banyak nasabah yang hanya membuka rekening tabungan untuk beberapa saat kemudian dana yang dimiliki akan ditarik kembali. PT Bank Tabungan Negara (Persero) KCS Malang berhasil memperoleh dana Deposito Batara iB periode tahun 2010 dan 2011 sebesar:

Tabel 1. Jumlah Dana Deposito Batara iB

\begin{tabular}{cc}
\hline Periode & Jumlah Dana Deposito Batara iB \\
\hline Tahun 2010 & $\operatorname{Rp} 64.874 .019 .799$ \\
Tahun 2011 & $\operatorname{Rp} 74.230 .381 .099$ \\
\hline
\end{tabular}

Sumber: Accounting\&Controlling PT Bank Tabungan Negara (Persero) KCS Malang

Berdasarkan data di atas dapat diketahui bahwa terjadi peningkatan perolehan dana Deposito Batara iB dalam periode dua tahun. Guna mempertahankan perolehan dana Deposito Batara iB yang semakin baik tersebut, PT Bank Tabungan Negara (Persero) KCS Malang memberikan strategi produk melalui fitur dan layanan yang menarik bagi nasabah. Penciptaan sebuah produk yang diharapkan dapat diterima nasabah dilakukan PT Bank Tabungan Negara (Persero) KCS Malang melalui pemberian merk, fitur dan layanan, logo serta motto. Strategi harga diterapkan pula pada Deposito Batara iB dalam bentuk pemberian nisbah bagi hasil dan tidak membebani nasabah dengan biaya administrasi serta penalty. PT Bank Tabungan Negara (Persero) KCS Malangmemberikan kepada nasabah Deposito Batara iB tersebut melalui kegiatan promosi dengan berbagai media. Melalui promosi ini nasabah akan mengetahui adanya produk Deposito Batara iB dan diharapkan akan memperoleh respon yang semakin baik dari nasabah. Strategi produk, harga dan promosi yang dilakukan PT Bank Tabungan Negara (Persero) KCS Malang diharapkan dapat mempertahankan peningkatan perolehan dana Deposito Batara iB agar dapat selalu stabil.

\section{STRATEGI PRODUK BANK}

\section{Pengertian Produk Bank}

Menurut Kotlerdalam Kasmir (2005:136) produk adalah sesuatu yang dapat ditawarkan ke pasar untuk mendapatkan perhatian untuk dibeli, untuk digunakan atau dikonsumsi yang dapat memenuhi keinginan dan kebutuhan. Produk adalah 
sesuatu yang memberikan manfaat baik dalam hal memenuhi kebutuhan seharihari atau sesuatu yang ingin dimiliki oleh konsumen(Kasmir, 2005:136).

Penciptaan sebuah produk harus menyesuaikan dengan sasaran pasar. Sehingga produk yang dihasilkan akan memberikan kepuasan kepada konsumen. Pada dunia perbankan syariah, produk yang dihasilkan adalah jasa. Produk jasa tersebut harus memperhatikan kualitas yang sesuai dengan keinginan nasabah. Sehingga produk yang ditawarkan tersebut dapat menarik nasabah baru atau mempertahankan nasabah yang telah ada. Berdasarkan uraian di atas dapat disimpulkan bahwa produk merupakan suatu barang atau jasa yang dapat digunakan untuk memenuhi kebutuhan konsumen atau nasabah. Pada dunia perbankan produk yang ditawarkan berupa jasa. Sehingga produk tersebut bersifat tidak berwujud (tangible).

\section{Ciri-Ciri Produk Bank}

Pada dunia perbankan baik syariah maupun konvensional, produk yang ditawarkan adalah produk dalam bentuk jasa khususnya jasa keuangan. Produk jasa tersebut memiliki ciri-ciri sebagai berikut: (1) Tidak berwujud (Tangibility), jasa bersifat abstrak dan tidak berwujud. (2) Tidak Terpisahkan (Inspirability). Jasa pada umumnya diproduksi dan dikonsumsi pada waktu yang bersamaan dengan partisipasi konsumen dalam prosesnya. (3) Beraneka Ragam (Variability), jasa bersifat non standar dan sangat variabel. (4) Tidak Tahan Lama, jasa tidak mungkin disimpan dalam bentuk persediaan (Rambat Lupiyoadi, 2006:84).

\section{Strategi Produk Bank}

Setiap bank yang meluncurkan sebuah produk selalu mengharapkan produk tersebut akan mendapat respon yang positif dari nasabah. Oleh karena itu, untuk mendapatkan hal itu sebuah bank harus mampu menerapkan strategi produk yang baik yang dapat mengena kepada nasabah. Dalam dunia perbankan strategi produk yang dilakukan untuk mengembangkan suatu produk adalah:

\section{Penentuan Logo dan Moto}

Logo merupakan ciri khas suatu bank. Logo dan moto dikatakan sebagi ciri dari sebuah produk. Oleh karena itu logo dan moto harus dirancang dengan benar. Pertimbangan pembuatan logo dan moto adalah sebagai berikut: (a) Memiliki arti (dalam arti positif), (b) Menarik perhatian, (c) Mudah diingat. Logo merupakan suatu bentuk gambar atau sekedar sketsa dengan arti tertentu dan mewakili suatu arti dari perusahaan, daerah, perkumpulan, produk, negara serta hal-hal lainnya yang dianggap membutuhkan hal yang singkat dan mudah diingat sebagai pengganti dari nama sebenarnya (pendidikan, 2010).

Sedangkan moto merupakan serangkaian kata-kata yang berisikan visi dan misi bank dalam melayani masyarakat (Kasmir, 2005:141). Motto memiliki tugas 
sebagai: (a) Untuk mengkomunikasikan secara singkat dan padat tentang janji produk. (b) Mengkomunikasikan pula merk dari produknya. (c) Sebisanya juga memuat benefit dari produk itu sendiri (d) Dapat menggambarkan personality produknya (santoso, 2008). Berdasarkan penjelasan di atas dapat disimpulkan bahwa penentuan logo dan motto harus sesuai dengan produk yang dimaksud. Logo dan motto harus pula mudah dimengerti dan diingat sehingga dapat menarik nasabah.

\section{Menciptakan Merk}

Merk merupakan suatu nama, frase, desain, lambang atau beberapa kombinasinya yang menjadi identifikasi jasa suatu perusahaan dan membedakannya dari para pesaing (Christopher H. Lovelock, 2005:178). Menurut Kasmir (2005:141) merk adalah nama dari sebuah produk. Produk jasa yang ada pada bank harus memiliki nama agar mudah diingat oleh nasabah. Pengertian merk sering diartikan sering diartikan sebagai simbol, nama, istilah, desain atau kombinasi dari semuanya.

Dalam penciptaan merk harus mempertimbangkan faktor-faktor: (a) Mudah diingat dan menarik perhatian. (b) Terkesan hebat dan modern. (c) Memiliki arti (dalam arti positif). Menurut Avijit Ghosh dalam Rambat Lupiyoadi (2006:87) ada tiga jenis merk, yaitu: (a) Manufacturer brands: diciptakan dan didistribusikan oleh perusahaan pembuat produk tersebut. (b) House brands: merk yang dikembangkan oleh toko tempat produk dijual. (c) Generic brands: produk tanpa merk tertentu. Berdasarkan yang telah diungkapkan di atas dapat disimpulkan bahwa penentuan merk merupakan salah satu strategi produk sebuah bank. Merk merupakan sebuah nama atas produk bank yang bersangkutan sehingga mudah untuk dikatakan dalam pengungkapannya.

\section{Menciptakan Kemasan}

Kemasan merupakan pembungkus suatu produk. Dalam dunia perbankan kemasan lebih diartikan kepada pemberian pelayanan atau jasa kepada para nasabah di samping juga sebagai pembungkus untuk beberapa jenis jasanya seperti buku tabungan, cek, bilyet giro atau kartu kredit (Kasmir, 2005:141). Menurut Kotler (1997:458) kemasan adalah kegiatan merancang dan memproduksi wadah kemas atau pembungkus suatu produk (Petra, 2005). Pendapat para ahli tersebut dapat disimpulkan bahwa kemasan adalah memproduksi bungkus atas sebuah produk yang diciptakan.

\section{Penentuan Label}

Label merupakan sesuatu yang ditempelkan pada produk yang ditawarkan dan merupakan bagian dari kemasan. Di dalam label dijelaskan siapa yang membuat, di mana dibuat, kapan dibuat dan informasi lainnya. Label pada sebuah produk perbankan dapat berupa brosur (Kasmir, 2005:142). Menurut Kotler (2002:478) label adalah tempelan sederhana pada produk atau gambar yang dirancang dengan 
rumit yang merupakan satu kesatuan dengan kemasan. Label memiliki fungsi sebagai berikut: (a) Mengidentifikasi produk dan merk. (b) Menentukan kelas produk. (c) Menjelaskan produk secara spesifik (Petra, 2005). Sedangkan label sendiri memiliki fungsi sebagai berikut: (a) Dengan melekatkan label, berarti produsen memberikan keterangan yang diperlakukan oleh para konsumen agar dapat memilih dan meneliti produk secara bijaksana. (b) Merupakan jaminan bahwa barang yang telah dipilih tidak berbahaya. (c) Bagi produsen, label dapat digunakan sebagai alat promosi terhadap produk tersebut (Fie, 2011). Berdasarkan penjelasan di atas dapat disimpulkan bahwa label merupakan bagian kemasan yang berisi tentang informasi produk yang bersangkutan.

\section{STRATEGI HARGA BANK}

\section{Pengertian Harga Bank}

Harga adalah suatu nilai tukar dari produk barang maupun jasa yang dinyatakan dalam satuan moneter. Harga merupakan salah satu penentu keberhasilan suatu perusahaan karena harga menentukan seberapa besar keuntungan yang akan diperoleh perusahaan dari penjualan produknya baik berupa barang atau jasa (Komunitas Perpustakaan Online, 2008). Menurut Matius (1999:24) harga adalah jumlah uang yang harus konsumen bayarkan untuk mendapatkan suatu produk. Sedangkan menurut Kotler (2001:439) harga merupakan sejumlah uang yang dibebankan atas suatu produk atau jasa, atau jumlah dari nilai yang ditukar konsumen atas manfaatmanfaat karena memiliki atau menggunakan produk atau jasa tersebut (wikimedya, 2009).

Penentuan harga merupakan salah satu aspek penting dalam kegiatan pemasaran. Harga menjadi sangat penting untuk diperhatikan mengingat harga sangat menentukan laku tidaknya suatu produk dan jasa perbankan. Salah dalam penentuan harga akan berakibat fatal terhadap produk yang ditawarkan nantinya. Bagi perbankan konvensional, harga yang merupakan komponen utama faktor biaya dan pendapatan bagi bank adalah bunga, biaya administrasi, biaya komisi dan provisi, biaya tagih, biaya sewa, biaya iuran dan biaya lain-lain. Sedangkan harga pada sebuah bank syariah adalah nisbah, bagi hasil dan ujrah.

Nisbah bagi hasil tersebut harus menyesuaikan dengan kebutuhan bank syariah untuk mendapatkan laba namun tetap sesuai dengan kemampuan nasabah. Misalnya, bank syariah memberikan nisbah bagi hasil yang sedikit lebih tinggi dari pembiayaan namun tetap memperhatikan sisi keuntungan bagi bank syariah yang bersangkutan. Melalui hal ini nasabah akan menanamkan dananya pada bank syariah yang dapat disalurkan pada produk pembiayaan (Kasmir, 2005:151). Berdasarkan penjelasan di atas dapat disimpulkan bahwa harga adalah sejumlah uang yang harus dikeluarkan oleh konsumen untuk mendapatkan produk atau jasa yang dibelinya guna memenuhi kebutuhan dan keinginannya. 


\section{Tujuan Penentuan Harga}

Tujuan penentuan harga bank dirasa penting karena apabila terdapat kesalahan dapat menyebabkan kerugian pada bank itu sendiri. Oleh karena itu, dalam menentukan harga, bank harus memiliki tujuan yang jelas apa kegunaan harga tersebut dan harus sesuai dengan produk yang ditawarkan kepada nasabah.Tujuan penentuan harga secara umum adalah sebagai berikut:

1. Bertahan

Bertahan merupakan usaha untuk tidak melakukan tindakan-tindakan yang meningkatkan laba ketika perusahaan sedang mengalami kondisi pasar yang tidak menguntungkan. Usaha ini dilakukan demi kelangsungan hidup perusahaan (Rambat Lupiyoadi, 2006:100).

2. Untuk memaksimalkan laba

Tujuan harga ini dengan mengharapkan penjualan yang meningkat sehingga laba dapat ditingkatkan. Penentuan harga biasanya dapat dilakukan dengan harga murah atau tinggi.

3. Untuk memperbesar Market Share

Penentuan harga ini dengan yang murah, sehingga diharapkan jumlah nasabah meningkat dan diharapkan pula nasabah pesaing beralih ke produk yang ditawarkan. Misalnya pemberian nisbah bagi hasil dalam produk simpanan atau pendanaan yang lebih tinggi dari pesaing dan dapat juga menambahkan sebuah hadiah.

4. Mutu Produk

Tujuan dalam hal mutu produk adalah untuk memberikan kesan bahwa produk atau jasa yang ditawarkan memiliki kualitas yang tinggi dan harga pun menyesuaikan pula.

5. Karena Pesaing

Dalam hal ini, penentuan harga dengan melihat pesaing. Tujuannya adalah agar harga yang ditawarkan tidak melebihi harga pesaing (Kasmir, 2005:153).

6. Gengsi atau prestis

Tujuan harga di sini adalah untuk memosisikan jasa perusahaan jasa tersebut sebagai jasa yang eksklusif (Rambat Lupiyoadi, 2006:100).

\section{Metode Penentuan Harga Bank}

Setelah ditentukan tujuan penentuan harga, maka untuk menentukan besarnya harga digunakan beberapa metode penentuan suatu harga produk bank. Dalam penentuan harga jasa bank secara umum adalah:

1. Modifikasi harga atau diskriminasi yang dapat dilakukan; (a) Menurut pelanggan, yaitu harga yang dibedakan berdasarkan nasabah utama (primer) atau nasabah biasa (sekunder). Nasabah utama adalah nasabah yang loyal dan memenuhi kriteria yang ditetapkan oleh bank. Nasabah biasa adalah nasabah umum. 
(b)Menurut bentuk produk, harga ditentukan berdasarkan bentuk produk atau kelebihan-kelebihan yang dimiliki oleh suatu produk, misalnya untuk kartu kredit ada visa card dan master card. (c) Menurut tempat, yaitu harga yang ditentukan berdasarkan lokasi cabang bank di mana produk atau jasa ditawarkan. (d) Menurut waktu, yaitu harga yang ditentukan berdasarkan periode atau masa tertentu dapat berupa jam, hari, mingguan atau bulanan (Kasmir,2005:160).

2. Penetapan Harga untuk Produk Baru. Sebuah bank meluncurkan sebuah produk, seperti bank mengeluarkan kartu kredit sehingga perlu ditentukan berapa iuran per bulan dan berapa bunga atau nisbah yang dikenakan setiap transaksi; (a) Market skimming pricing, yaitu harga awal produk yang ditetapkan setinggitingginya dengan tujuan bahwa produk atau jasa memiliki kualitas tinggi. (b) Market penetration pricing, yaitu dengan menetapkan harga yang serendah mungkin dengan tujuan untuk menguasai pasar (Kasmir, 2005:160). Menurut Rambat Lupiyoadi (2006:108) apabila ancaman persaingan muncul, sebaiknya menetapkan harga yang rendah. Apabila tidak ada ancaman, maka menggunakan metode harga skimming.

\section{STRATEGI PROMOSI BANK}

Produk selesai diciptkan dan harga telah ditentukan, maka untuk menjual produk tersebut harus melalui kegiatan promosi. Melalui kegiatan promosi tersebut nasabah akan dapat mengenal produk yang ditawarkan sehingga tertarik untuk membeli atau menggunakannya. Menurut Gugup Kismono menyatakan bahwa promosi adalah usaha yang dilakukan untuk mempengaruhi konsumen dan pihak lain melalui aktivitas-aktivitas jangka pendek sehingga konsumen dapat terpengaruh(bapepam, 2007).

Uraian di atas menjelaskan bahwa promosi merupakan kegiatan untuk memberikan informasi kepada konsumen akan sebuah produk. Sedangkan dalam dunia perbankan, promosi merupakan kegiatan bank untuk memberikan informasi kepada nasabah atas produk dan jasa yang dimiliki baik secara langsung maupun tidak langsung. Promosi dapat berfungsi untuk menarik nasabah menggunakan produk jasa yang diberikan. Selain itu promosi juga mengingatkan nasabah atas produk yang dimiliki bank.

Secara garis besar saran promosi yang dapat digunakan oleh perbankan adalah:

1. Periklanan (Advertising)

Periklanan merupakan salah satu bentuk dari komunikasi impersonal (impersonal communication) yang digunakan oleh perusahaan barang atau jasa (Rambat Lupiyoadi, 2006:120). Menurut Kasmir (2005:177) iklan adalah sarana promosi yang digunakan oleh bank guna menginformasikan, segala sesuatu produk yang dihasilkan oleh bank. Tujuan promosi melalui iklan adalah berusaha untuk menarik dan mempengaruhi calon nasabahnya. Penggunaan promosi 
dengan iklan dapat dilakukan dengan berbagai media, seperti : (a) Pemasangan Billboard (papan nama) di jalan-jalan strategis; (b) Pencetakan brosur, iklan melalui televisi, radio, koran; (c) Pemasangan spanduk di lokasi tertentu yang strategis; Agar iklan yang dijalankan efektif dan efisien maka perlu dilakukan program pemasaran yang tepat. Program periklanan yang harus dilalui adalah: (a) Identifikasikan pasar sasaran dan motif pembeli. (b) Tentukan misi yang menyangkut sasaran penjualan dan tujuan periklanan. (c) Anggaran iklan yang ditetapkan.

2. Merancang pesan yang akan disampaikan dan memilih media.

Menentukan penggunaan media iklan tergantung pada tujuan bank karena masing-masing media memiliki tujuan yang berbeda. Iklan sebagai media promosi memiliki tujuan yaitu: (a) Untuk pemberitahuan segala sesuatu yang berkaitan dengan produk dan jasa bank yang dimiliki oleh suatu bank. Misalnya memberitahukan adanya produk baru atau pembukaan kantor cabang baru.

(b) Untuk mengingatkan kembali nasabah tentang keunggulan atau keberadaan jasa bank yang ditawarkan. Terlalu banyaknya pesaing membuat sebuah bank harus selalu mengingatkan nasabahnya agar tidak berpindah pada bank lain. (c) Mempengaruhi nasabah saingan agar berpindah kepada bank yang memasang iklan. (d) Membangun citra perbankan untuk jangka panjang, baik untuk produk yang dihasilkan maupun nama bank (Kasmir, 2005:177).

Melakukan promosi melalui iklan memiliki beberapa keunggulan. Keunggulan tersebut yaitu: (a) Presentasi Publik, artinya, iklan menawarkan pesan yang sama kepada banyak orang. (b) Pervasivenes, yaitu memungkinkan perusahaan atau bank untuk mengulang pesan berulang kali. (c) Amplied expressiveness, Yaitu berpeluang untuk mendramatisir produk melalui pemanfaatan suara, warna atau bentuk produk. (d) Impersonality, maksudnya konsumen atau nasabah tidak wajib untuk memperhatikan dan merespon iklan sekarang (Kasmir, 2005:179). Berdasarkan yang telah dibahas di atas dapat dikatakan melakukan kegiatan promosi melalui media periklanan (advertising) dapat menarik minat nasabah untuk menggunakan jasa perbankan. Melalui iklan tersebut nasabah akam mengetahui bagaimana keunggulan sebuah bank dan produk-produknya.

3. Promosi Penjualan (Sales Promotion)

Promosi penjualan merupakan insentif jangka pendek untuk meningkatkan pembelian atau penjualan produk atau jasa untuk menarik tanggapan yang lebih cepat dan kuat dari nasabah. Manfaat yang diberikan promosi melalui sales promotion adalah: (a) Komunikasi, yaitu memberikan informasi yang dapat menarik perhatian nasabah untuk membeli produk atau jasa bank. (b) Insentif, yaitu memberikan dorongan dan semangat kepada nasabah untuk segera membeli produk yang ditawarkan. (c) Invitasi mengharapkan nasabah segera merealisasi pembelian (Kasmir, 2005:180). 
Promosi penjualan merupakan pelengkap bagi promosi yang lainnya. Promosi penjualan apabila digunakan dengan tepat, bisa menjadi efektif, untuk mendukung promosi lainnya. Promosi penjualan dapat mendorong efektivitas pembelian konsumen dan pedagang dengan menggunakan alat-alat peragaan, demonstrasi dan sebagainya (Kasmir, 2005:180). Bagi sebuah bank promosi penjualan dapat dilakukan melalui: (a) Pemberian bunga khusus (spesial rate) bagi bank konvensional dan special nisbah bagi bank syariah untuk jumlah dana yang relatif besar; (b) Pemberian insentif kepada setiap nasabah yang memiliki simpanan dengan saldo tertentu; (c) Pemberian cinderamata, hadiah serta kenang-kenangan kepada nasabah yang loyal; dan sebagainya (Kasmir, 2005:180).

Menggunakan media sales promotion, nasabah akan mendapatkan berbagai kenyamanan dan fasilitas yang menyenangkan. Melalui kupon, hadiah maupun undian nasabah akan mendapatkan keistimewaan tersendiri akan sebuah produk yang belum tentu dimiliki oleh pesaing. Hal ini akan menjadi pertimbangan bagi nasabah untuk tidak berpindah kepada bank lain.

4. Publisitas (Publicity)

Menurut Kasmir (2005:181) publisitas merupakan kegiatan promosi untuk memancing nasabah melalui kegiatan seperti pameran, bakti sosial serta kegiatan lainnya. Publisitas dapat didefinisikan sebagai informasi tentang seseorang, produk atau organisasi yang disebarluaskan pada masyarakat melalui media tanpa dipungut biaya. Sebelum produk diluncurkan oleh bank atau pada waktu produk itu mulai diperkenalkan, bank akan mendahuluinya dengan memberitakan tentang barang yang dihasilkan tersebut kepada publik melalui media tertentu.

Kegiatan publisitas dapat meningkatkan citra bank di mata para nasabah. Nasabah akan selalu mengingat akan bank dan produk-produknya dan diharapkan dapat meningkatkan jumlah nasabah kembali. Kegiatan publisitas dapat dilakukan melalui; (a) Mengikuti pameran, (b) Kegiatan sosial. (c) Sponsorship kegiatan, (d) Kegiatan-kegiatan untuk memperingati perayaan tertentu yang berguna untuk menciptakan hubungan yang erat dengan nasabah (Kasmir, 2005:181).

5. Penjualan Pribadi (Personal Selling)

Penjualan secara pribadi merupakan alat yang paling efektif pada tahap akhir berupa proses pembelian, khususnya dalam membangun preferensi, keyakinan dan tindakan pembeli. Penjualan perorangan dapat juga didefinisikan sebagai penjualan dengan tatap muka pada calon nasabah produk yang dihasilkan oleh bank. Penjualan secara personal selling memberikan beberapa keuntungan bagi bank, yaitu antara lain: (a) Bank dapat langsung bertatap muka dengan nasabah atau calon nasabah, sehingga dapat langsung menjelaskan tentang produk bank secara rinci.(b) Dapat memperoleh informasi langsung dari nasabah 
tentang kelemahan produk bank yang bersangkutan. (c) Pegawai bank dapat langsung mempengaruhi nasabah dengan berbagai argumen yang dimiliki. (d) Memungkinkan hubungan terjalin akrab antara pihak bank dengan nasabah. (e) Apabila pihak bank memberikan pelayanan yang baik maka akan memperbaiki citra bank di mata nasabah. (f) Membuat situasi seolah-oleh mengharuskan nasabah mendengarkan, memperhatikan dan menanggapi bank (Kasmir, 2005: 182)

Dalam dunia perbankan penjualan pribadi secara umum dilakukan oleh seluruh pegawai bank, mulai dari cleaning service, satpam hingga pejabat bank. Personal selling juga melalui merekrut tenaga-tenaga untuk melakukan penjualan door to door. Secara khusus Personal Selling dilakukan oleh pegawai bagian Customer Service atau Service Assistensi (Kasmir, 2005:182). Berdasarkan yang telah diungkapkan di atas dapat disimpulkan bahwa segala macam bentuk promosi, promosi bank bertujuan untuk mengajak nasabah untuk membeli produk dari bank tersebut dan memberikan informasi pada nasabah tentang produk bank. Melalui kegiatan promosi inilah bank dapat mencapai target yang diinginkan dalam memperoleh laba dan nasabah dapat memperoleh kepuasan pula atas produk dan pelayanan yang diberikan oleh bank.

6. Pemasaran Langsung (Direct Marketing)

Pemasaran langsung dapat menggunakan dengan area direct marketing, mail order, direct selling, telemarketing dan digital marketing (Rambat Lupiyoadi, 2006:122). Menurut Fandy Tjiptono, keunikan utama direct marketing antara lain: (a) Pesan yang disampaikan kepada audiensi secara spesifik dan tidak bersifat massal. (b) Dapat dirancang dan disiapkan khusus untuk menarik pelanggan individual yang dituju. (c) Pesan dapat dirubah sesuai dengan respon pelanggan (Wimma Yukedea,2010:15).

7. Hubungan Masyarakat (Public Relation)

Hubungan masyarakat merupakan kiat pemasaran penting lainnya, dimana perusahaan tidak hanya berhubungan dengan pelanggan, pemasok dan penyalur, tetapi juga berhubungan dengan kumpulan kepentingan publik yang lebih besar. Hubungan masyarakat sangat peduli terhadap beberap tugas pemasaran, antara lain: (a) Membangun citra (b) Mendukung aktivitas komunikasi lainnya (c) Mempengaruhi publik yang spesifik. (d) Mengadakan peluncuran untuk produk atau jasa baru (Rambat Lupiyoadi, 2006:122).

\section{METODE}

Penelitian ini dilakukan pada PT Bank Tabungan Negara (Persero) Kantor Cabang Syariah Malang yang terletak di Jalan Bandung No. 40 Malang. Penelitian ini merupakan jenis penelitian kualitatif dengan pendekatan deskriptif. yang mana peneliti berusaha menggambarkan bagaimana strategi produk, harga dan promosi 
pada Deposito Batara iB di PT Bank Tabungan Negara (Persero) KCS Malang. Menurut Moleong, metode kualitatif adalah penelitian yang memiliki maksud untuk memahami fenomena tentang apa yang dialami oleh subyek penelitian, misalnya perilaku, persepsi, motivasi, tindakan dll, secara holistic dan dengan cara deskripsi dalam bentuk kata-kata dan bahasa pada suatu kontek khusus yang alamiah dan dengan memanfaatkan berbagai metode ilmiah (Afifah, 2008:44)

Menurut Sugiyono (2008:289) penelitian melalui pendekatan deskriptif adalah penelitian yang memandu peneliti untuk mengekplorasi dan atau memotret situasi yang akan diteliti secara menyeluruh, luas dan mendalam (Umi Rodiyah, 2009:49). Dalam penelitian ini digunakan data primer dan data sekunder. Yang mana data primer merupakan data yang diperoleh secara langsung dari sumber berupa penjelasan maupun keterangan melalui wawancara dengan pihak yang terkait dengan strategi produk, harga dan promosi Deposito Batara iB di PT. Bank Tabungan Negara (Persero) KCS Malang. Sedangkan data sekunder merupakan data yang diperoleh secara tidak langsung berupa data lain yang diperoleh melalui studi kepustakaan berupa literatur, jurnal, makalah, buletin, internet, dan sumber lainnya yang berkaitan dengan masalah yang diteliti.

Teknik pengumpulan data yang digunakan oleh peneliti dalam penelitian ini yaitu wawancara, dan dokumentasi. Penelitian ini menggunakan metode penelitian kualitatif, sehingga instrumen penelitian adalah peneliti. Kehadiran peneliti di PT Bank Tabungan Negara (Persero) KCS Malang menjadi syarat mutlak.

\section{PEMBAHASAN HASIL PENELITIAN}

\section{Strategi Produk pada Deposito Batara iB}

Deposito Batara iB merupakan produk penyimpanan dana dalam bentuk deposito dengan akad mudharabah mutlaqah untuk tujuan investasi dalam jangka waktu tertentu sesuai pilihan dan kebutuhan nasabah. Mudharabah mutlaqah yang berarti pemilik dana (deposan) tidak memberikan batasan tertentu kepada bank syariah dalam mengelola investasinya, baik yang berkaitan dengan tempat, cara maupun objek investasinya. Deposito Batara iB merupakan produk investasi dalam jangka pendek menengah. Melalui Deposito Batara iB, nasabah dapat menginvestasikan dananya yang dapat dicairkan pada jangka waktu tertentu sesuai dengan kebutuhan nasabah. Berdasarkan hasil wawancara yang dilakukan dengan Bapak Anang Pranoto Hidayat selaku Jr. Consumer Funding Marketing Officer PT Bank Tabungan Negara (Persero) KCS Malang, pemberian Deposito Batara iB diharapkan dapat memenuhi kebutuhan nasabah. Oleh sebab itu yang dilakukan dalam menciptakan Deposito Batara iB melalui berbagai tahap (seperti yang diungkapkan dalam wawancara), yaitu: 


\section{1) Penentuan Logo dan Motto}

Logo Deposito Batara iB digunakan adalah logo PT. Bank Tabungan Negara (Persero) KCS Malang yang berbentuk sebagai berikut:

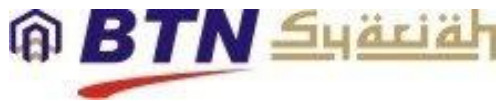

\section{Gambar 2. Logo Deposito Batara iB}

Logo tersebut mengambil pola segi enam. Pola ini mengambil bentuk sarang lebah, yang menyiratkan adanya kegiatan menabung pada masyarakat, sebagaimana halnya lebah yang selalu menyimpan madu perolehannya. Dengan lambang ini, BTN Syariah melaksanakan pembagunan nasional dengan mengerahkan dana masyarakat berbentuk tabungan. Pola ini juga menyiratkan "Atap Rumah" yang menjadi citra dan misi utama BTN Syariah, sebagai pelaksana KPR bagi masyarakat.

Dalam penentuan motto, Deposito Batara iB memiliki motto "sarana investasi dana yang aman dan terpercaya". Motto tersebut memiliki arti nasabah dapat melakukan investasi secara aman pada PT. Bank Tabungan Negara (Persero) KCS Malang. PT Bank Tabungan Negara (Persero) KCS Malang tidak akan menyelewengkan dana Deposito Batara iB. Deposito Batara iB merupakan pula sarana investasi yang terpercaya baik secara prinsip syariah maupun kejujuran dalam transaksi. Segala hal yang menjadi hak nasabah PT Bank Tabungan Negara (Persero) KCS Malang tidak akan melalaikannya.

\section{2) Penciptaan Merk}

Merk yang tertera dalam produk deposito di PT Bank Tabungan Negara (Persero) KCS Malang adalah "Batara iB". Kata "Batara" dalam merk tersebut merupakan singkatan dari Bank Tabungan Negara dan diikuti pula dengan "iB" yang berarti islamic banking (bank syariah). Oleh sebab itu, Deposito Batara iB merupakan produk pendanaan dalam bentuk investasi yang dimiliki oleh PT. Bank Tabungan Negara (Persero) KCS Malang.

\section{3) Penciptaan Kemasan}

Kemasan dalam Deposito Batara iB berupa fitur dan layanan untuk nasabah. Fitur dan layanan tersebut adalah sebagai berikut:

a. Sarana investasi dana yang aman dan terpercaya.

b. Bagi hasil yang menarik dan dapat diakumulasikan ke dalam pokok deposito.

c. Bebas memilih cara perpanjangan, Automatic Roll Over (ARO) atau Non ARO. Apabila tiba waktu jatuh tempo, seorang deposan tidak memberikan konfirmasi atas pencairan depositonya, maka secara otomatis pihak PT Bank Tabungan Negara (Persero) KCS Malang akan memperpanjang 
deposito hingga waktu yang ditentukan oleh deposan di kemudian hari. Hal tersebut dinyatakan melalui perjanjian ketika akad.

d. Pencairan sebelum jatuh tempo tidak dikenakan penalty.

e. Dapat digunakan sebagai sarana penyaluran zakat, infak dan sadaqah.

f. Jangka waktu penempatan cukup fleksibel, yaitu 1, 3, 6, 12 dan 24 bulan.

g. Nominal penempatan cukup terjangkau yaitu minimal Rp 500.000,- untuk perorangan dan Rp 2.500.000,- untuk perusahaan atau lembaga.

Selain hal tersebut, kemasan Deposito Batara iB berupa pula Bilyet Deposito yang diberikan kepada nasabah sebagai bukti bahwa nasabah tersebut memiliki simpanan Deposito Batara iB di PT Bank Tabungan Negara (Persero) KCS Malang. Bilyet Deposito Batara iB diciptakan dengan lembaran berbentuk persegi panjang yang dikelilingi ukiran akrelik pada bagian tepinya. Pada bagian atas terdapat tulisan bismillah dengan huruf arab dan huruf latin. Kemudian di bawah kata bismillah terdapat tulisan "Deposito Batara iB" yang menandakan bahwa lembaran tersebut merupakan bilyet produk Deposito Batara iB.

Pada sisi kiri atas terdapat logo PT Bank Tabungan Negara (Persero) KCS Malang. Hal tersebut sebagai bukti bahwa Deposito Batara iB merupakan produk PT Bank Tabungan Negara (Persero) KCS Malang. Bagian bawah logo, terdapat No. Seri bilyet yang diikuti dengan identitas deposan serta keterangan mengenai hal-hal yang terkait tentang Deposito Batara iB seperti nisbah yang diperoleh, sistem perpanjangan yang dilakukan, tanggal jatuh tempo dan bulan penerimaan bagi hasil.

Pada bagian kiri bawah terdapat tanda tangan deposan dan pada bagian kanan terdapat tanda tangan pihak PT Bank Tabungan Negara (Persero) KCS Malang yang dilengkapi dengan materai. Hal tersebut sebagai bukti bahwa segala ketentuan yang terdapat dalam Deposito Batara iB telah disetujui kedua belah pihak".

\section{4) Penentuan Label}

Label yang ada pada Deposito Batara iB adalah brosur. Brosur Deposito Batara iB berada pada satu lembaran bersama dengan produk simpanan dana yang lain, yaitu Tabungan Batara iB dan Giro Batara iB. Brosur tersebut berisi tentang fitur dan layanan serta informasi-informasi tentang Deposito Batara iB.

\section{Strategi Harga pada Deposito Batara iB}

Penentuan harga merupakan salah satu aspek penting pada sebuah produk. Begitu pula pada produk Deposito Batara iB di PT Bank Tabungan Negara (Persero) KCS Malang. Produk deposito yang telah dikemas perlu adanya sebuah harga yang diberikan kepada nasabah. Nominal minimum pembukaan rekening Deposito Batara iB merupakan harga yang diberikan. Sesuai dengan strategi produk yang mengikuti target pasar yang dituju, Deposito Batara iB memberikan nominal 
pembukaan rekening dengan rendah. Dengan dana Rp 500.000,- nasabah dapat membuka rekening Deposito Batara iB. Oleh sebab itu, harga yang dimiliki Deposito Batara iB akan mudah dijangkau oleh nasabah.

Harga pada produk bank syariah berupa pula pada nisbah bagi hasil. Bagi hasil Deposito Batara iB tidak dapat dipastikan nominalnya karena bagi hasil bergantung pada pendapatan PT Bank Tabungan Negara (Persero) KCS Malang. Pendapatan tersebut adalah laba pada bisnis dalam bentuk pembiayaan yang dijalankan pihak bank, seperti yang diungkapkan Ibu Siska Mariana selaku Customer Service dalam wawancara:

"Bagi hasil Deposito Batara iB tidak dapat ditentukan nominalnya secara pasti, karena bagi hasil kita bersumber dari pendapatan bank. Pendapatan bank tersebut berasal dari bisnis pembiayaan".

Pembagian perolehan nisbah bagi hasil Deposito Batara iB pada PT Bank Tabungan Negara (Persero) KCS Malang dapat dijelaskan dalam tabel sebagai berikut:

Tabel 1. PerolehanNisbah Bagi Hasil Deposito Batara iB Periode Bulan April 2012

\begin{tabular}{ccc}
\hline \multirow{2}{*}{ Jangka Waktu Deposito Batara iB } & \multicolumn{2}{c}{ Nisbah Bagi Hasil } \\
\cline { 2 - 3 } & Nasabah & Bank Syariah \\
\hline 1 bulan & $50 \%$ & $50 \%$ \\
3 bulan & $50 \%$ & $50 \%$ \\
6 bulan & $49 \%$ & $51 \%$ \\
12 bulan & $49 \%$ & $51 \%$ \\
24 bulan & $61 \%$ & $39 \%$ \\
\hline
\end{tabular}

Sumber: Customer Service PT. Bank Tabungan Negara (Persero) KCS Malang

Berdasarkan tabel di atas dapat diketahui prosentase yang diperoleh nasabah dan pihak PT Bank Tabungan Negara (Persero) KCS Malang. Prosentase tersebut dapat berubah setiap waktu. Begitu pula dengan nominal bagi hasil dari Deposito Batara iB. Oleh sebab itu, pihak PT Bank Tabungan Negara (Persero) KCS Malang tidak memberikan janji yang pasti atas nominal bagi hasil kepada nasabah. Namun pada akad di awal pihak PT Bank Tabungan Negara (Persero) KCS Malang akan memberikan kisaran perolehan bagi hasil untuk nasabah. Pemberian nisbah bagi hasil deposito yang menguntungkan merupakan salah satu bentuk aplikasi strategi harga Deposito Batara iB.

Berdasarkan hasil wawancara dengan Ibu Siska Mariana selaku Customer Service, perhitungan pendapatan PT Bank Tabungan Negara (Persero) KCS Malang menggunakan sistem profit sharing yang berarti laba atas pembiayaan telah dikurangi seluruh biaya-biaya yang diperlukan (laba bersih). Langkah-langkah menentukan bagi hasil Deposito Batara iB bagi nasabah adalah sebagai berikut: 
(a) Menetapkan nisbah bagi hasil Deposito Batara iB; (b) Menghitung saldo ratarata Deposito Batara $\mathrm{iB}$; (c) Menghitung total saldo rata-rata Deposito Batara iB; (d) Menghitung jumlah pendapatan PT h Bank Tabungan Negara (Persero) KCS Malang.

Melalui langkah-langkah penentuan bagi hasil di atas diperoleh perhitungan bagi hasil Deposito Batara iB dengan rumus:

Nominal x pendapatan $\mathrm{x}$ nisbah

saldo rata-rata

Contoh perhitungan bagi hasil akan disajikan dalam kasus sebagai berikut:

Seorang deposan dengan nominal Rp 60.000.000 jangka waktu 1 bulan. Beliau menempatkan dananya pada 1 April 2012. Berdasarkan data pendapatan PT Bank Tabungan Negara (Persero) KCS Malang pada bulan April 2012 sebesar Rp11.821.604.424. Sedangkan saldo rata-rata Deposito Batara iB jangka waktu 1 bulan pada bulan April sebesar Rp1.131.843.544.265. Bagi hasil yang dapat diperoleh deposan tersebut adalah:

Bagi hasil nasabah $=\frac{60.000 .000 \times 11.821 .604 .424 \times 50 \%}{1.131 .843 .544 .265}=\operatorname{Rp} 2.224 .485$

Sedangkan keuntungan bagi hasil untuk pihak PT. Bank Tabungan Negara (Persero) KCS Malang adalah:

Bagi hasil bank $=\frac{60.000 .000 \times 11.821 .604 .424 \times 50 \%}{1.131 .843 .544 .265}=\operatorname{Rp} 2.224 .485$

Nisbah bagi hasil Deposito Batara iB tidak hanya akan diberikan dengan prosentase yang sama kepada seluruh deposan. Deposito Batara iB memberikan sebuah hadiah dalam bentuk nisbah spesial pada deposan tertentu. Salah satu syarat untuk mendapatkan nisbah spesial adalah pembukaan rekening Deposito Batara iB dengan nominal yang tertera pada tabel berikut:

Tabel 2. Special Nisbah Deposito Batara iB Periode Februari-April 2012

\begin{tabular}{lcc}
\hline Nasabah & Nominal Minimal & Nisbah Maksimal \\
\hline Perorangan & 100 juta $-<=250$ juta & $54,56 \%$ \\
& $>250$ juta $-<=500$ juta & $56,50 \%$ \\
& $>500$ juta $-<=1 \mathrm{M}$ & $58,45 \%$ \\
Lembaga & $>1 \mathrm{M}$ & $60,40 \%$ \\
& 100 juta $-<=500$ juta & $54,56 \%$ \\
& $>500$ juta $-<=1 \mathrm{M}$ & $56,50 \%$ \\
& $>1 \mathrm{M}$ & $58,45 \%$ \\
\hline
\end{tabular}

Sumber: Customer Service PT Bank Tabungan Negara (Persero) KCS Malang 
Selain nominal pembukaan rekening tertentu Deposito Batara iB, nisbah spesial diberikan kepada deposan yang memiliki hubungan baik dengan PT Bank Tabungan Negara (Persero) KCS Malang, misalnya pada deposan yang memiliki tingkat loyalitas cukup tinggi. Pada beberapa produk dana PT Bank Tabungan Negara (Persero) KCS Malang diterapkan adanya biaya administrasi yang dikenakan pada nasabah setiap bulan. Namun biaya administrasi tersebut tidak diberlakukan pada Deposito Batara iB. Berdasarkan hasil wawancara dengan Bapak Anang Pranoto Hidayat selaku Jr. Consumer Funding Marketing Officer dikatakan bahwa adanya biaya administrasi tidak sesuai dengan prinsip syariah. Oleh sebab itu Deposito Batara iB tidak memberikan biaya administrasi pada deposannya.

Selain biaya administrasi, Deposito Batara iB tidak pula menerapkan adanya biaya penalty apabila terjadi pencairan sebelum jatuh tempo. Apabila terjadi pencairan dana sebelum jatuh tempo maka pihak PT Bank Tabungan Negara (Persero) KCS Malang hanya akan memberikan nominal pokok Deposito Batara iB milik deposan yang bersangkutan tanpa bagi hasil pada periode bulan berjalan.

\section{Strategi Promosi pada Deposito Batara iB}

Berdasarkan hasil wawancara dengan Bapak Anang Pranoto Hidayat selaku Jr. Consumer Funding Marketing Officer, produk Deposito Batara iB diperkenalkan kepada nasabah melalui kegiatan promosi. Promosi merupakan salah satu kegiatan yang penting. Melalui promosi masyarakat akan mengetahui akan adanya produk Deposito Batara iB dan mengingatkan kembali pada beberapa nasabah dengan keberadaan Deposito Batara iB. Berdasarkan hasil wawancara yang diperoleh, strategi promosi yang dilakukan untuk Deposito Batara iB telah dilakukan secara maksimal sesuai dengan kemampuan PT Bank Tabungan Negara (Persero) KCS Malang. Melakukan kegiatan promosi melalui berbagai macam cara dan media dilakukan oleh PT Bank Tabungan Negara (Persero) KCS Malang.

Kegiatan promosi yang dilakukan PT. Bank Tabungan Negara (Persero) KCS Malang pada produk Deposito Batara iB adalah sebagai berikut:

\section{Periklanan}

Tujuan promosi melalui iklan adalah berusaha untuk menarik dan mempengaruhi calon nasabahnya. Media periklanan yang biasa digunakan oleh PT Bank Tabungan Negara (Persero) KCS Malang dalam kegiatan promosi produk Deposito Batara iB:

a. Radio. Dalam melakukan kegiatan promosi dengan media radio, PT Bank Tabungan Negara(Persero) KCS Malang memperhatikan dan mempertimbangkan waktu penayangan, segmen pendengar dan moment yang tepat. Sebagai contoh, pada bulan Ramadan PT Bank Tabungan Negara (Persero) KCS Malang memasang iklan melalui radio pada waktu berbuka puasa. Selain melakukan promosi produk Deposito Batara iB dan produk lainnya, 
PT Bank Tabungan Negara (Persero) KCS Malang sekaligus mengucapkan selamat berbuka puasa kepada masyarakat.

b. Televisi. PT Bank Tabungan Negara (Persero) KCS Malang hanya menggunakan media televisi lokal (Malang TV), karena melihat target pasar yang hanya di wilayah kota Malang dan sekitarnya.

c. Koran. PT Bank Tabungan Negara (Persero) KCS Malang biasa menggunakan koran sebagai sarana periklanan. Hal ini dipilih karena biasanya iklan dipasang sesuai dengan waktu yang tepat dengan acara PT Bank Tabungan Negara (Persero) KCS Malang dan biaya yang relatif rendah. Koran yang digunakan sebagai media promosi PT. Bank Tabungan Negara (Persero) KCS Malang adalah Jawa Pos, Kompas dan Radar Malang.

d. Brosur. Brosur Deposito Batara iB diletakkan pada meja Customer Service, Payment Point, disebarluaskan dalam acara pameran, open table, acara sponsorship, lingkungan perguruan tinggi dan lingkungan sekolah.

e. Bilboard. Bilboard biasa dipasang pada jalan-jalan utama kota Malang sehingga dapat jelas dipandang pengguna jalan.

f. Papan Produk. Papan produk Deposito Batara iB diletakkan pada dinding di belakang Customer Service. Sehingga ketika nasabah berada pada Customer Service dapat membaca papan produk tersebut.

\section{Penjualan Pribadi (Personal Selling)}

Penjualan secara pribadi merupakan alat yang paling efektif pada pembelian oleh nasabah. Penjualan personal untuk Deposito Batara iB dilakukan dengan mengadakan kunjungan secara langsung kepada nasabah sehingga lebih mengenai sasaran. Personal selling Deposito Batara iB dilakukan oleh bagian Customer Servicedan Jr. Consumer Funding Marketing Officer. Seperti presentasi pada kegiatan sponsorship, penjelasan langsung kepada nasabah yang datang dan kunjungan berbagai instansi, seperti perguruan tinggi.

\section{Promosi Penjualan (Sales Promotion)}

Media yang digunakan PT. Bank Tabungan Negara (Persero) KCS Malang dalam melakukan Sales Promotion adalah: (a) Hadiah atau souvenir. Hadiah untuk produk Deposito Batara iB diberikan pada saat pembukaan rekening. Hadiah yang diberikan berupa payung, bantal, termos, jam dinding, gelas, boneka dan sebagainya. Hadiah yang diberikan tidak bergantung pada syarat tertentu. Namun hadiah tersebut diberikan kepada deposan sesuai dengan ketersediaan atas hadiah tersebut. (b) Pemberian khusus, seperti nisbah spesial pada deposan dengan nominal pembukaan rekening tertentu. 


\section{Publisitas (Publicity)}

Kegiatan publisitas dilakukan PT. Bank Tabungan Negara (Persero) KCS Malang melalui media sebagai berikut:

a. Seminar. PT Bank Tabungan Negara (Persero) KCS Malang seringkali menjadi sponsor atau menjadi penyelenggara kegiatan-kegiatan seminar perbankan syariah yang biasanya diadakan di perguruan tinggi.

b. Open Table. Kegiatan open table yang diadakan PT Bank Tabungan Negara (Persero) KCS Malang di beberapa instansi menjadi salah satu media untuk menginformasikanDeposito Batara iB pada masyarakat. Instansi yang pernah menjadi lokasi kegiatan open table PT Bank Tabungan Negara (Persero) KCS Malang antara lain Bentoel, Sampoerna, Jasa Tirta, Universitas Islam Negeri Maulana Malik Ibrahim Malang dan beberapa perguruan tinggi lainnya.

c. Website Perusahaan. Menurut hasil dari data sekunder, PT Bank Tabungan Negara (Persero) Syariah memiliki websiteyang dapat digunakan sebagai sarana promosi produk-produknya, termasuk Deposito Batara iB di PT Bank Tabungan Negara (Persero) KCS Malang. Website PT Bank Tabungan Negara (Persero) Syariah dapat diakses langsung pada www.btn.co.id/syariah.

Aplikasi strategi promosi yang telah diterapkan PT Bank Tabungan Negara (Persero) KCS Malang memberikan kesempatan bagi nasabah untuk lebih memperkenalkan dan memulihkan kembali ingatan nasabah akan Deposito Batara iB. Bahwa Deposito Batara iB merupakan produk yang menarik bagi nasabah.

Deposito Batara iB merupakan produk penyimpanan dana dalam bentuk deposito dengan akad mudharabah mutlaqah untuk tujuan investasi dalam jangka waktu tertentu sesuai pilihan dan kebutuhan nasabah. Mudharabah mutlaqah yang berarti pemilik dana (deposan) tidak memberikan batasan tertentu pada bank syariah dalam mengelola investasinya, baik yang berkaitan dengan tempat, cara maupun objek investasinya. Hal tersebut sesuai dengan yang telah disampaikan pada Fatwa DSN No. 03/DSN-MUI/IV/2000 tentang Deposito yang mengatakan bahwa deposito secara syariah adalah deposito yang menggunakan prinsip mudharabah.

Strategi produk Deposito Batara iB dilakukan pula oleh PT Bank Tabungan Negara (Persero) KCS Malang berdasarkan prinsip syariah. Berdasarkan pada Fatwa DSN No. 03/DSN-MUI/IV/2000 tentang Deposito, transaksi dalam deposito syariah, bank sebagai mudharib (pengelola dana) dan nasabah sebagai shahibul maal (pemilik dana). Sebagai mudharib bank dapat melakukan berbagai macam usaha yang tidak bertentangan dengan prinsip syariah, bahkan dapat melakukan prinsip mudharabah dengan pihak lain. Dana yang diperoleh atas Deposito Batara iB disalurkan oleh pihak PT Bank Tabungan Negara (Persero) KCS Malang ke dalam usahanya yaitu pembiayaan. Melalui berbagai macam pembiayaan dengan beberapa prinsip syariah, antara lain pembiayaan KPR BTN iB yang menggunakan prinsip murabahah (jual beli), pembiayaan modal kerja BTN iB dengan prinsip 
mudharabah dan sebagainya. Deposito sesuai syariah menyatakan bahwa modal harus dinyatakan jumlahnya dan dalam bentuk tunai, bukan piutang. Setoran awal pembukaan rekening Deposito Batara iB nasabah harus memberikan dana dalam bentuk uang tunai. Dapat pula dengan menggunakan pemindah bukuan. Namun dalam keadaan tunai keberadaannya (bukan masih milik orang lain yang berhutang pada nasabah tersebut).

Berdasarkan penjelasan di atas dapat disimpulkan bahwa PT Bank Tabungan Negara (Persero) KCS Malang tidak memberikan produk yang haram dan menentang prinsip syariah. Strategi produk Deposito Batara iB yang telah dilakukan PT Bank Tabungan Negara (Persero) KCS Malangbelum sesuai dengan teori yang ada dalam penciptaan merk dan kemasan serta penentuan logo dan motto. Deposito Batara iB dalam penciptaan label tidak spesifik. Label dalam bentuk brosur Deposito Batara iB menjadi satu lembaran dengan produk yang lain sehingga nasabah tidak dapat fokus terhadap satu produk, Deposito Batara iB saja. Dari segi konvensional maupun segi syariah dan didukung dengan penelitian terdahulu tentang aplikasi sebuah produk kepada nasabah yang ditulis oleh Afifah (2008) dengan judul "Aplikasi Produk Share Bank Muamalat Indonesia (BMI) (Studi Pada Bank Muamalat Cabang Malang).

Penentuan harga merupakan salah satu aspek penting pada sebuah produk. Harga menjadi sangat penting untuk diperhatikan mengingat harga sangat menentukan laku atau tidaknya suatu produk. Salah dalam penentuan harga akan berakibat fatal terhadap produk yang ditawarkan nantinya (Kasmir, 2005:151). Harga pada Deposito Batara iB adalah nominal pembukaan rekening dan bagi hasil. Nominal pembukaan rekening yang terjangkau ditetapkan karena mengikuti target pasar PT Bank Tabungan Negara (Persero) KCS Malang. Sedangkan bagi hasil Deposito Batara iB telah ditetapkan nisbahnya yang disepakati antara nasabah dengan pihak bank. Penentuan harga Deposito Batara iB tersebut menggunakan metode penentuan harga market penetration pricing.

Modifikasi harga terhadap sebuah produk dapat dilakukan dengan membedakan harga berdasarkan nasabah utama (primer) atau nasabah biasa (sekunder). Nasabah utama adalah nasabah yang loyal dan memenuhi kriteria yang ditetapkan oleh bank dan nasabah sekunder adalah nasabah biasa (Kasmir, 2005:160). Strategi harga diberikan PT. Bank Tabungan Negara (Persero) KCS Malang melalui pemberian special nisbah kepada nasabah utama. Nasabah yang memenuhi ketentuan PT. Bank Tabungan Negara (Persero) KCS Malang untuk berhak mendapatkan special nisbah. Sedangkan nasabah dengan kategori nasabah sekunder akan mendapatkan nisbah bagi hasil Deposito Batara iB yang biasa.

Menurut Fatwa DSN No. 03/DSN-MUI/IV/2000 tentang Deposito, Pembagian keuntungan atas deposito syariah harus dinyatakan dalam bentuk nisbah dan dituangkan dalam akad pembukaan rekening. Deposito Batara iB menggunakan nisbah bagi hasil dalam perolehan keuntungan. Nisbah bagi hasil tersebut telah 
dibagi sesuai ketetapan antara PT Bank Tabungan Negara (Persero) KCS Malang dengan nasabah dan dituangkan dalam aplikasi pembukaan rekening Deposito Batara iB. Selain itu, pihak PT Bank Tabungan Negara (Persero) KCS Malang memiliki papan pembagian nisbah bagi hasil Deposito Batara iB yang dipasang pada dinding yang tepat berada di belakang meja Customer Service. Sehingga nasabah yang akan membuka rekening Deposito Batara iB akan mengetahui dengan jelas akan nisbah bagi hasil atas Deposito Batara iB.

Dalam prinsip syariah, pihak bank selaku mudharib menutup biaya operasional deposito dengan menggunakan nisbah keuntungan yang menjadi haknya. Deposito Batara iB tidak menerapkan adanya biaya administrasi dan biaya penalty. Pihak PT Bank Tabungan Negara (Persero) KCS Malang memberikan nisbah bagi hasil kepada nasabah dan menerima keuntungan dalam bentuk bagi hasil tanpa biayabiaya operasional lainnya.

Berdasarkan penjelasan di atas dapat dikatakan bahwa strategi harga Deposito Batara iB telah diaplikasikan sesuai dengan teori yang ada. Secara umum atau konvensional telah sesuai begitu pula secara syariah dan didukung pula oleh penelitian terdahulu yang ditulis oleh Afifah (2008) dengan judul "Aplikasi Produk Shar-e Bank Muamalat Indonesia (BMI) (Studi Pada Bank Muamalat Cabang Malang). Produk bank syariah memberikan harga kepada nasabah dengan bagi hasil.

PT Bank Tabungan Negara (Persero) KCS Malang menginformasikan Deposito Batara iB kepada nasabah melalui kegiatan promosi. Promosi Deposito Batara iB dilakukan sebaik mungkin sesuai dengan kemampuan PT Bank Tabungan Negara (Persero) KCS Malang. Strategi promosi Deposito Batara iB dilakukan dengan melakukan kegiatan promosi melalui berbagai macam media. Kegiatan promosi Deposito Batara iB yang dilakukan PT Bank Tabungan Negara (Persero) KCS Malang adalah sebagai berikut:

1. Periklanan

Menurut Kasmir (2005:177) iklan adalah sarana promosi yang digunakan oleh bank guna menginformasikan segala sesuatu produk yang dihasilkan oleh bank. PT. Bank Tabungan Negara (Persero) KCS Malang melakukan promosi melalui periklanan melalui media radio, televisi, koran, brosur, pemasangan billboard dan papan produk yang diletakkan pada dinding Customer Service.

2. Penjualan Pribadi (Personal Selling)

Penjualan secara personal selling memberikan keuntungan kepada bank. Pihak bank akan dapat bertatap muka secara langsung dengan calon nasabah sehingga dapat dengan mudah menjelaskan tentang produk bank secara rinci. Pegawai bank dapat pula secara langsung mempengaruhi nasabah dengan berbagai argumen yang dimiliki dan memungkinkan terjalin hubungan yang akrab antara pihak bank dengan nasabah (Kasmir, 2005:181). Penjualan secara 
personal selling Deposito Batara iB dilakukan dengan mengadakan kunjungan secara langsung kepada nasabah, presentasi pada kegiatan sponsorship, penjelasan secara langsung kepada nasabah yang datang pada PT Bank Tabungan Negara (Persero) KCS Malang dan mengadakan kunjungan ke berbagai instansi. Kegiatan promosi Deposito Batara iB secara personal selling di PT Bank Tabungan Negara (Persero) KCS Malang dilakukan oleh Customer Service dan Jr. Consumer Funding Marketing Officer.

\section{Promosi Penjualan (Sales Promotion)}

Promosi penjualan merupakan insentif jangka pendek untuk meningkatkan pembelian atas penyediaan produk jasa guna menarik tanggapan yang lebih cepat dan kuat dari nasabah (Kasmir, 2005:179). PT Bank Tabungan Negara (Persero) KCS Malang melakukan sales promotion Deposito Batara iB dengan melakukan pemberian hadiah atau souvenir kepada nasabah ketika pembukaan rekening Deposito Batara iB. Selain itu, PT. Bank Tabungan Negara (Persero) KCS Malang memberikan pula special nisbah kepada nasabah sesuai dengan ketentuan yang ditetapkan pihak bank.

\section{Publicity}

Publicity adalah kegiatan promosi untuk memancing nasabah melalui kegiatan seperti pameran, bakti sosial serta kegiatan yang berguna untuk menciptakan hubungan yang erat dengan nasabah (Kasmir,2005:181). Promosi Deposito Batara iB dengan kegiatan publicity dengan PT. Bank Tabungan Negara (Persero) KCS Malang dilakukan dengan mengikuti seminar tentang perbankan syariah, kegiatan open table dan website perusahaan. Strategi promosi PT. Bank Tabungan Negara (Persero) KCS Malang diterapkan pula pada prinsip syariah.

Strategi promosi Deposito Batara iB yang dilakukan PT Bank Tabungan Negara (Persero) KCS Malang tidak dilakukan dengan manipulasi maupun menipu nasabah. Nasabah akan memperoleh informasi Deposito Batara iB secara benar sesuai dengan kenyataan produk tersebut. PT Bank Tabungan Negara (Persero) KCS Malang dalam melakukan promosi menggunakan media-media yang tidak dilarang oleh agama. Berdasarkan penjelasan di atas, PT Bank Tabungan Negara (Persero) KCS Malang tidak menerapkan konsep direct marketing dan hubungan masyarakat dalam promosinya. Sehingga strategi promosi yang dilakukan PT Bank Tabungan Negara (Persero) KCS Malang belum sesuai dengan teori dalam perbankan. 


\section{KESIMPULAN DAN SARAN}

\section{Kesimpulan}

Bentuk fisik deposito pada PT Bank Tabungan Negara (Persero) KCS Malang diciptakan dengan logo PT Bank Tabungan Negara (Persero) KCS Malang dan "sarana investasi dana yang aman dan terpercaya" sebagai mottonya. Merk "Batara iB" dibubuhkan pula sebagai tanda bahwa deposito tersebut merupakan produk yang dimiliki PT Bank Tabungan Negara (Persero) KCS Malang. Selain itu, kemasan Deposito Batara iB diberikan kepada nasabah dalam bentuk berbagai fitur dan layanan serta bilyet deposito yang diperoleh nasabah.

Strategi harga diterapkan pada Deposito Batara iB dengan memberikan nominal yang terjangkau untuk pembukaan rekening. Strategi harga Deposito Batara iB diterapkan pula dengan memberikan nisbah bagi hasil yang menarik, pemberian special rate dan tidak dikenakannya biaya administrasi dan penalty dalam transaksinya.

Deposito Batara iB diperkenalkan kepada nasabah melalui kegiatan promosi. Promosi melalui media radio, televisi, koran dan media lainnya diharapkan mampu memberikan informasi kepada nasabah tentang Deposito Batara iB. PT Bank Tabungan Negara (Persero) KCS Malang melakukan pula strategi promosi melalui personal selling yang dilakukan oleh Customer Service dan Jr. Consumer Funding Marketing Officer sertapemberian hadiah dan souvenir pada pembukaan rekening Deposito Batara iB. Mengikuti berbagai macam kegiatan seperti pameran, open table, menjadi sponsorship sebuah kegiatan maupun melakukan kunjungan pada instansi merupakan strategi dalam promosi Deposito Batara iB yang dilakukan PT. Bank Tabungan Negara (Persero) KCS Malang.

\section{Saran}

Dalam aplikasi strategi promosi, PT Bank Tabungan Negara (Persero) KCS Malang sebaiknya menerapkandirect marketing dan hubungan masyarakat agar promosi yang dilakukan lebih luas melalui berbagai media dan semakin mengena kepada nasabah. Sehingga Deposito Batara iB dapat lebih dikenal kepada nasabah dan dapat pula meningkatkan dana. PT Bank Tabungan Negara (Persero) KCS Malang dalam menentukan harga sebaiknya ada kala menggunakan metode market skimming pricing. Ketika dirasa tidak terdapat ancaman pesaing, PT Bank Tabungan Negara (Persero) KCS Malang dapat menggunakan metode tersebut. Hal tersebut diiringi pula dengan kualitas produk yang tinggi. Dapat dilakukan dengan menaikkan nominal pembukaan rekening Deposito Batara iB serta memberikan nisbah bagi hasil untuk nasabah lebih tinggi. Dapat pula dengan menurunkan syarat untuk mendapatkan nisbah special. Sehingga nasabah dapat merasakan bahwa Deposito Batara iB adalah produk yang berkualitas tinggi. Penentuan label pada Deposito Batara iB dalam bentuk brosur sebaiknya PT Bank Tabungan Negara 
(Persero) KCS Malang menciptakan brosur yang khusus untum produk Deposito Batara iB. Sehingga lebih tampak keistimewaan produk tersebut dan nasabah tidak menentukan pilihan ke produk yang lain.

\section{DAFTAR PUSTAKA}

Afifah. 2008. Aplikasi Produk Shar-e Bank Muamalat Indonesia (BMI) (Studi Pada Bank Muamalat Cabang Malang). Skripsi. Malang: FE-UIN.

Bapepam. 2007. Studi Analisa Program Promosi dan Pengenalan Produk Pasar Modal dan Jasa Keuangan Oleh Pelaku Industri Jasa Keuangan Retrieved 25 Mei, 2012, from www.bapepam.go.id

BTN. (2009) Retrieved 23 Mei, 2012, from www.btn.co.id/syariah

Christopher, H., Lovelock, L.K.W. 2005. Manajemen Pemasaran Jasa. Jakarta: Indeks.

DSN. 2010. Fatwa DSN No. 03/DSN-MUI/IV/2000 tentang Deposito Retrieved 22 Mei, 2012, from www.mui.or.id/index

Fie. 2011. Pengertian Label di Indonesia Retrieved 13 Juli, 2012, from www.scribd.com

Pendidikan, i. 2010. Pengertian Logo Retrieved 13, 2012, from pendidikan.info.com/pengertian logo.

Kasmir, S. 2005. Pemasaran Bank (Vol. Edisi Pertama). Jakarta: Kencana.

Petra, U.K. 2005. Faktor-Faktor Pembentuk Persepsi Konsumen Terhadap Kemasan Retrieved 13 Juli, 2012, from digilib.petra.ac.id

Rambat, Lupiyoadi, A.H. 2006. Manajemen Pemasaran Jasa. Jakarta: Salemba Empat.

Santoso, B. 2008. Perbankan Retrieved 13 Juli, 2012, from budisantoso.ucoz.com/perbankan.

Wikimedya. 2009. Pengertian Harga (Price) Retrieved 14 Juli, 2012, from wikimedya. blogspot. com

Wimma, Y. 2010. Pelaksanaan Promosi yang Efektif untuk Meningkatkan Volume Penjualan di PT bank Tabungan Negara (Persero) Kantor Cabang Syariah Malang. Laporan Akhir. Malang: Administrasi Niaga-Politeknik Negeri Malang.

Kotler, P., dan Armstrong, G. 2002. Prinsip-Prinsip Pemasaran (edisi 12). Jakarta: Erlangga. 